\title{
Effects of Seeding Dates on Yield and Feed Value of Italian Ryegrass in Paddy Field Cultivation
}

\author{
Sang Moo Lee \\ Department of Animal Science, Kyungpook National University, Sangju-Si 742-711, Korea
}

\begin{abstract}
This study was carried out to investigate the influence of the seeding dates on the yield and feed value in cultivating Italian rye grass on paddy soil. The field experiment was designed in a randomized block design of 3 repetitions with seeding dates of Oct. 19 (T1), Oct. 26 (T2), Nov. 2 (T3), Nov. 9 (T4), and Nov. 16 (T5) treatments. Plant length, fresh yield, dry matter yield and TDN yield were increased with early seeding dates $(\mathrm{p}<0.05)$. Crude protein, Crude fat and crude ash were increased with early seeding dates $(\mathrm{p}<0.05)$. On the other hand, NDF, ADF and Crude fiber were decreased with early seeding dates $(\mathrm{p}<0.05)$. Total mineral contents were higher in the order of $\mathrm{T} 4>\mathrm{T} 3>\mathrm{T} 5>\mathrm{T} 1>\mathrm{T} 2(\mathrm{p}<0.05)$. The total composition amino acid content was decreased significantly $(\mathrm{p}<0.05)$ as the seeding dates delayed. Total free sugar content was highest in T1, whereas the lowest in T5 treatment $(\mathrm{p}<0.05)$. Nutrition yields (crude protein, crude fat, amino acid and free sugar) were increased significantly with early seeding dates $(\mathrm{p}<0.05)$.

The above result indicated that it is favorable to seed soon after rice harvest to increase dry matter yield and nutrition yield of Italian ryegrass in the midlands
\end{abstract}

(Key words : Italian ryegrass, Seeding dates, Dry matter yield, Nutritional yield)

\section{I . INTRODUCTION}

As domestic Hanwoo and beef cattle breeding herd number reaches 3,100,000, there is an increased demand for roughage and concentrate. However, because there is a limited production capability for roughage and grains, dependancy on foreign import is rising. Because imported hay and grain has a high price fluctuation depending on international supply capacity, it is a difficult situation for farmers to reliably maintain the livestock industry (Lee and Kim., 2013). Therefore, expanding the base for domestic roughage to create a production infrastructure to make it possible to stock breed reliably. Especially, using abandoned farmlands after rice crop cultivation in a country with small land mass like Korea is a very important method in increasing roughage production (Kim et al., 2006). The crop fit for this is Italian rye grass which has strong moisture tolerance for paddy fields (Kim et al., 2007), has a high hay yield (Kim et al., 2009), and has a high palatability which makes it recommended as a winter crop (Choi et al., 2006a). Also Italian rye grass has a higher ratio of leaves to stems which makes it high silage quality. It is a plant that can produce dry hay in spring season (Seo et al., 2013). While until now it was only cultivated in the southern because of its low cold tolerance, there recently has been new varieties that have high cold tolerance that made it possible to cultivate it in the midlands (Kim et al., 2007; Kim et al., 2009). About research in Korea for Italian rye grass, there are many results of selection test through new varieties adaptiveness (Kim et al., 1998; Choi et al., 2005, 2006a, 2006b, 2007, 2008) and dry matter yield and nutritive value test (Chae et al., 1996; Kim et al., 2007; Seo et al., 2013). However, studies on the mineral contents, amino acid compositions, free sugars and nutrient yields were not reported. Therefore this research was done to investigate the effects on yield and nutritive value that seeding date after rice cultivation has. For the basic data, yield, TDN yield, mineral elements, amino acid composition, free sugar content, and nutrition yield was investigated. Also the results of this study will be used in figuring out the adequate seeding date for Italian rye grass to provide

* Corresponding author: Sang Moo Lee, Department of Animal Science, Kyungpook National University, Sangju 742-711. Korea. Tel: +82-54-530-1224. E-mail: smlee0103@knu.ac.kr 
basic data for establishing a safe cultivation technique in paddy field.

\section{ПI. MATERIALS AND METHODS}

This field experiment was performed from October $19^{\text {th }}$ 2009 to May $21^{\text {th }} 2010$ at a paddy field in the northwestern inland of Gyeongbuk. The field experiment design was randomized complete block in five factors with three replicates (see Table 1 ).

The conditions of the field experiment were a paddy field with higher organic matter and nitrogen content and lower phosphate content than the general upland soil as shown in Table 2. And the weather conditions during the experimental period are shown in Table 3.

The application rates of chemical fertilizer were calculated in total nitrogen (200 kg/ha), phosphorus (150 $\mathrm{kg} / \mathrm{ha}$ ) and potassium contents (150 kg/ha). The method of chemical fertilizer application was applied nitrogen and potassium with $40 \%$ as basis of fertilizer, and $60 \%$ as added fertilizer and entire phosphorus as the basis of fertilizer. The seeding method of Italian ryegrass was broadcasted on the soil at the rate of $50 \mathrm{~kg} / \mathrm{ha}$. The test plot area was $3 \mathrm{~m} \times 5 \mathrm{~m}=15 \mathrm{~m}^{2}$. Fresh yield was counted after cutting of $9 \mathrm{~m}^{2}$ each repetition. The samples were dried for 5 days at $55^{\circ} \mathrm{C}$ to use as analysis samples. Nutritive values were analyzed using the AOAC method (1995); ADF and NDF were analyzed by Goering and Van Soest method (1970). TDN was obtained by the formula of Menke and Huss (1980): TDN $=88.9-(0.79 \times \mathrm{ADF})$. The mineral composition was analyzed from of the pre-treated samples using ICP (Inductively Coupled Plasma, Iris Intrepid, Thermo Elemental Co., UK). The analysis of composition amino acid was done in the following sequence: $1 \mathrm{~g}$ of the pulverized sample was precisely taken and put in to a test tube; $10 \mathrm{~mL}$ of $6 \mathrm{~N}-\mathrm{HCl}$ was added, pressure reduced and

Table 1. Experimental design

\begin{tabular}{lccccc}
\hline \multirow{2}{*}{ Item } & \multicolumn{5}{c}{ Treatments } \\
\cline { 2 - 6 } & T1 & T2 & T3 & T4 & T5 \\
\hline \hline Seeding date (2009) & Oct. 19 & Oct. 26 & Nov. 2 & Nov. 9 & Nov. 16 \\
\hline Harvest date (2010) & May 21 & May 21 & May 21 & May 21 & May 21 \\
\hline Cultivation period & 215 days & 208 days & 201 days & 194 days & 187 days \\
\hline
\end{tabular}

Table 2. Chemical properties of the soil before experiment

\begin{tabular}{|c|c|c|c|c|c|c|c|c|}
\hline \multirow{2}{*}{$\begin{array}{c}\mathrm{pH} \\
(1: 5) \\
\end{array}$} & \multirow{2}{*}{$\begin{array}{l}\mathrm{OM} \\
(\%)\end{array}$} & \multirow{2}{*}{$\begin{array}{l}\mathrm{T}-\mathrm{N} \\
(\%) \\
\end{array}$} & \multirow{2}{*}{$\begin{array}{c}\text { Av. } \mathrm{P}_{2} \mathrm{O}_{5} \\
(\mathrm{mg} / \mathrm{kg})\end{array}$} & \multicolumn{4}{|c|}{ Ex. cation $\left(\mathrm{cmol}^{+} \mathrm{kg}^{-}\right)$} & \multirow{2}{*}{$\begin{array}{c}\text { CEC } \\
\left(\mathrm{cmol}^{+} \mathrm{kg}^{-}\right) \\
\end{array}$} \\
\hline & & & & $\mathrm{K}$ & $\mathrm{Na}$ & $\mathrm{Ca}$ & $\mathrm{Mg}$ & \\
\hline 6.34 & 2.62 & 0.15 & 102.67 & 0.58 & 0.18 & 3.68 & 0.87 & 13.4 \\
\hline
\end{tabular}

Table 3. Monthly meteorological data during the experimental period

\begin{tabular}{lcccr}
\hline Year Month & $\begin{array}{c}\text { Mean Temp. } \\
\left({ }^{\circ} \mathrm{C}\right)\end{array}$ & $\begin{array}{c}\text { Duration of sunshine } \\
(\mathrm{hr})\end{array}$ & $\begin{array}{c}\text { Precipitation } \\
(\mathrm{mm})\end{array}$ & $\begin{array}{c}\text { Rainy or snowy days } \\
(\text { day })\end{array}$ \\
\hline \hline 2009 October & 13.9 & 212 & 17.3 & 4 \\
November & 6.6 & 130 & 43.1 & 9 \\
December & -3.0 & 155 & 38.7 & 12 \\
\hline 2010 January & -2.6 & 186 & 23.2 & 11 \\
February & 1.1 & 128 & 78.4 & 18 \\
March & 4.6 & 127 & 80.7 & 18 \\
April & 9.8 & 177 & 58.9 & 9 \\
May & 17.6 & 228 & 118.2 & 9 \\
\hline
\end{tabular}


sealed; hydrolysis at $110^{\circ} \mathrm{C}$ in a dry oven for 24 hours; pre-treated and filtered by $0.45 \mu \mathrm{m}$ membrane filter; and the filtered sample was analyzed by amino acid automatic analyzer (Biochrom 30, Biochrom Ltd, Cambridge, England). Free sugar was analyzed in the following order: exactly $5 \mathrm{~g}$ of sample was taken per Wilson et al. method (1981); $100 \mathrm{~mL}$ of $80 \%$ ethanol solution was added; sugar composition was extracted repetitively for 2 hours at $80^{\circ} \mathrm{C}$ from the heating mantle in the reflux cooling extraction unit; filtered by Whatman No. 5 and pre-treated; and was analyzed with HPLC analyzer (Waters 2414, Waters Co, USA) respectively. Mean values and standard deviations of the experimental results were obtained using SAS (Statistics Analytical System, USA) Program (2010); Duncan’s multiple comparison test was used to identify differences among the treatments, which is considered significant when $\mathrm{p}<0.05$.

\section{RESULT AND DISCUSSION}

\section{Growth characteristics and dry matter yield}

The growth characteristics by seeding date is shown on Table 4. Plant length showed a high result in the order of $\mathrm{T} 1>\mathrm{T} 2>\mathrm{T} 3>\mathrm{T} 4>\mathrm{T} 5(\mathrm{p}<0.05)$. Like the kim et al. (2009) report, it was shown that Italian rye grass plant length was shorter at delayed seeding dates. Stem diameter did not show a significant difference. Fresh yield and dry matter yield was higher when seeding date was earlier $(\mathrm{p}<0.05)$, and especially there was a trend of rapidly decrease in yield after November in seeding dates (T3, T4, T5). The results liked the report from Kim et al.(2009) and Suh (1981) which said that when cultivating winter crops after rice cultivation, there was a difference in yield according to the seeding dates. Kim et al. (2008) reported that when seeding date is delayed in the autumn, the average temperature drops and it winter survival average rates rapidly decreases, which result in a reduced dry matter yield. It was shown that TDN yield was significantly higher in $\mathrm{T} 1$ than other treatments and especially in T3, T4 and T5 with late seeding dates showed a very low yield $(p<0.05)$. These results were consistent with the report of Kim et al. (2009) which described that TDN yield, and dry matter yield, increased with earlier seeding dates.

\section{Chemical compositions}

The chemical composition in accordance to seeding date for Italian ryegrass is shown on Table 5 . While the crude protein, crude fat, crude ash content of Italian ryegrass significantly decreased with earlier seeding dates $(\mathrm{p}<0.05)$, while NDF, ADF and crude fiber content increased with earlier seeding dates $(\mathrm{p}<0.05)$. This is because as cultivation period increases, maturity stages develop and the leaf ratio of the plant decreases and stems harden (Kim et al., 2007; Kim et. al., 2008; Lim and Kim; 1996). The chemical compositions of forage crop were reported represent significant differences depending on cutting times (Hwang et al., 2008), maturity stage (Seo et al., 2013), varieties

Table 4. Effects of seeding times on growth characteristics and yield of Italian ryegrass in the paddy field cultivation

\begin{tabular}{lccccc}
\hline \multirow{2}{*}{ Items } & \multicolumn{3}{c}{ Treatments } \\
\cline { 2 - 6 } & T1 & T2 & T3 & T4 & T5 \\
\hline \hline Plant length (cm) & $84.5 \pm 4.4^{\mathrm{a}}$ & $73.5 \pm 2.0^{\mathrm{b}}$ & $70.7 \pm 0.8^{\mathrm{bc}}$ & $66.9 \pm 2.4^{\mathrm{c}}$ & $61.8 \pm 1.8^{\mathrm{d}}$ \\
Stem diameter (mm) & $2.6 \pm 0.1^{\text {ns }}$ & $2.6 \pm 0.2$ & $2.4 \pm 0.3$ & $2.5 \pm 0.1$ & $2.7 \pm 0.1$ \\
Fresh yield (kg/ha) & $21,152 \pm 1,512^{\mathrm{a}}$ & $16,213 \pm 2,001^{\mathrm{b}}$ & $12,626 \pm 1,385^{\mathrm{c}}$ & $9,845 \pm 1,110^{\mathrm{d}}$ & $9,722 \pm 996^{\mathrm{d}}$ \\
Dry matter yield (kg/ha) & $4,076 \pm 290^{\mathrm{a}}$ & $3,056 \pm 377^{\mathrm{b}}$ & $2,315 \pm 254^{\mathrm{c}}$ & $1,784 \pm 209^{\mathrm{d}}$ & $1,712 \pm 176^{\mathrm{d}}$ \\
TDN $^{1)}$ yield (kg/ha) & $2,311 \pm 165^{\mathrm{a}}$ & $1,769 \pm 218^{\mathrm{b}}$ & $1,351 \pm 148^{\mathrm{c}}$ & $1,061 \pm 120^{\mathrm{c}}$ & $1,090 \pm 112^{\mathrm{c}}$ \\
\hline
\end{tabular}

$\mathrm{TDN}^{1)}$ : total digestible nutritions.

TDN yield $=[88.9-(0.79 \times \mathrm{ADF})] \times$ dry matter yield $/ \mathrm{ha}$.

Data are expressed as means $\pm \mathrm{SD}$.

ns : not significant.

a,b,c,d Means in a row with different superscripts are significantly different $(\mathrm{p}<0.05)$. 
Table 5. Effects of seeding times on chemical compositions of Italian ryegrass silage in the paddy field cultivation (DM, \%)

\begin{tabular}{lccccc}
\hline \multirow{2}{*}{ Items } & \multicolumn{5}{c}{ Treatments } \\
\cline { 2 - 6 } & \multicolumn{1}{c}{$\mathrm{T} 1$} & $\mathrm{~T} 2$ & $\mathrm{~T} 3$ & $\mathrm{~T} 4$ & $\mathrm{~T} 5$ \\
\hline \hline Crude protein & $15.4 \pm 0.5^{\mathrm{d}}$ & $16.0 \pm 0.3^{\mathrm{d}}$ & $18.5 \pm 0.5^{\mathrm{c}}$ & $20.1 \pm 0.6^{\mathrm{b}}$ & $21.3 \pm 0.4^{\mathrm{a}}$ \\
Crude fat & $2.3 \pm 0.1^{\mathrm{d}}$ & $2.1 \pm 0.1^{\mathrm{d}}$ & $2.4 \pm 0.2^{\mathrm{bc}}$ & $2.6 \pm 0.2^{\mathrm{b}}$ & $3.0 \pm 0.2^{\mathrm{a}}$ \\
Crude ash & $10.0 \pm 0.2^{\mathrm{b}}$ & $10.1 \pm 0.3^{\mathrm{b}}$ & $10.4 \pm 0.8^{\mathrm{b}}$ & $11.6 \pm 0.4^{\mathrm{a}}$ & $11.3 \pm 0.4^{\mathrm{a}}$ \\
$\mathrm{NDF}^{1)}$ & $53.7 \pm 1.6^{\mathrm{a}}$ & $53.4 \pm 1.3^{\mathrm{a}}$ & $48.2 \pm 1.8^{\mathrm{b}}$ & $47.3 \pm 0.4^{\mathrm{b}}$ & $47.0 \pm 0.9^{\mathrm{b}}$ \\
$\mathrm{ADF}^{2)}$ & $40.8 \pm 1.3^{\mathrm{a}}$ & $39.3 \pm 2.6^{\mathrm{a}}$ & $38.6 \pm 1.3^{\mathrm{a}}$ & $37.2 \pm 2.4^{\mathrm{a}}$ & $31.9 \pm 3.2^{\mathrm{b}}$ \\
Crude fiber $^{31.0 \pm 1.4^{\mathrm{a}}}$ & $32.3 \pm 1.7^{\mathrm{a}}$ & $26.7 \pm 2.3^{\mathrm{b}}$ & $24.4 \pm 1.5^{\mathrm{b}}$ & $24.3 \pm 1.1^{\mathrm{b}}$ \\
\hline
\end{tabular}

$\mathrm{NDF}^{1)}$ : neutral detergent fiber, $\mathrm{ADF}^{2)}$ : acid detergent fiber.

Data are expressed as means \pm SD.

a,b,c,d Means in a row with different superscripts are significantly different $(\mathrm{p}<0.05)$.

(Kim et al., 1998), seeding dates (Kim et al., 2009) and manure conditions (Lee, 2012). Feed value was shown to be high in the late seeding group (T4, T5), but as shown in Table 4, when seeding date is late, yield significantly decreases. Thus, seeding dates should be determined by considering dry matter yield and nutritional value at the same time.

\section{Mineral contents}

Mineral content according to seeding date is shown on Table 6. Irregardless of seeding date, the mineral contents of Italian rye grass were higher in the order of $\mathrm{K}>\mathrm{Ca}>$ $\mathrm{Na}>\mathrm{Mg}$. This result had the same trend as the report from Lee (2012). Excluding trace minerals (Co, Cu, Mn, Mo, Zn), Ca, K, Mg contents were the highest in T3 and

Table 6. Effects of seeding times on mineral contents of Italian ryegrass in the paddy field cultivation (DM, mg/kg)

\begin{tabular}{lccccc}
\hline \multirow{2}{*}{ Items } & \multicolumn{5}{c}{ Treatments } \\
\cline { 2 - 6 } & $\mathrm{T} 1$ & $\mathrm{~T} 2$ & $\mathrm{~T} 3$ & $\mathrm{~T} 4$ & $\mathrm{~T} 5$ \\
\hline \hline $\mathrm{Ca}$ & $12,806.2 \pm 999.3^{\mathrm{b}}$ & $12,570.9 \pm 1,008.8^{\mathrm{b}}$ & $14,171.7 \pm 1,047.6^{\mathrm{ab}}$ & $14,990.1 \pm 751.2^{\mathrm{a}}$ & $13,958.4 \pm 748.9^{\mathrm{b}}$ \\
$\mathrm{Co}$ & $0.2 \pm 0.0^{\mathrm{ns}}$ & $0.2 \pm 0.1$ & $0.3 \pm 0.1$ & $0.1 \pm 0.0$ & $0.1 \pm 0.0$ \\
$\mathrm{Cu}$ & $5.8 \pm 1.0^{\mathrm{b}}$ & $6.9 \pm 0.6^{\mathrm{ab}}$ & $8.0 \pm 0.7^{\mathrm{a}}$ & $7.1 \pm 0.4^{\mathrm{ab}}$ & $5.9 \pm 1.1^{\mathrm{b}}$ \\
$\mathrm{Fe}$ & $270.8 \pm 16.7^{\mathrm{bc}}$ & $293.9 \pm 16.7^{\mathrm{ab}}$ & $311.3 \pm 18.3^{\mathrm{a}}$ & $241.0 \pm 21.8^{\mathrm{c}}$ & $177.0 \pm 22.2^{\mathrm{d}}$ \\
$\mathrm{K}$ & $29,491.1 \pm 1,207.2^{\mathrm{ns}}$ & $29,068.9 \pm 1,453.6$ & $30,513.9 \pm 1,273.7$ & $31,889.4 \pm 1,882.7$ & $28,601.0 \pm 720.7$ \\
$\mathrm{Mg}$ & $984.2 \pm 135.5^{\mathrm{b}}$ & $989.7 \pm 147.8^{\mathrm{b}}$ & $1,299.5 \pm 70.8^{\mathrm{a}}$ & $1,261.4 \pm 120.9^{\mathrm{a}}$ & $768.4 \pm 23.7^{\mathrm{c}}$ \\
$\mathrm{Mn}$ & $40.9 \pm 5.8^{\mathrm{b}}$ & $48.7 \pm 2.9^{\mathrm{a}}$ & $55.6 \pm 3.4^{\mathrm{a}}$ & $33.2 \pm 4.2^{\mathrm{c}}$ & $33.8 \pm 1.7^{\mathrm{c}}$ \\
$\mathrm{Mo}$ & $0.6 \pm 0.1^{\mathrm{ns}}$ & $0.4 \pm 0.1$ & $0.4 \pm 0.1$ & $0.5 \pm 0.1$ & $0.5 \pm 0.1$ \\
$\mathrm{Na}$ & $944.9 \pm 103.5^{\mathrm{d}}$ & $1,160.8 \pm 67.6^{\mathrm{c}}$ & $1,324.5 \pm 65.4^{\mathrm{c}}$ & $1,510.2 \pm 156.1^{\mathrm{b}}$ & $1,855.7 \pm 81.6^{\mathrm{a}}$ \\
$\mathrm{Zn}$ & $20.9 \pm 1.9^{\mathrm{b}}$ & $23.1 \pm 1.9^{\mathrm{b}}$ & $33.0 \pm 3.4^{\mathrm{a}}$ & $23.5 \pm 1.1^{\mathrm{b}}$ & $21.1 \pm 1.9^{\mathrm{b}}$ \\
$\mathrm{P}$ & $388.5 \pm 63.5^{\mathrm{a}}$ & $314.0 \pm 21.6^{\mathrm{b}}$ & $248.6 \pm 21.7^{\mathrm{b}}$ & $252.2 \pm 28.8^{\mathrm{b}}$ & $274.7 \pm 14.4^{\mathrm{b}}$ \\
Total & $44,954.1 \pm 887.1^{\mathrm{bc}}$ & $44,477.5 \pm 769.5^{\mathrm{c}}$ & $47,966.8 \pm 1,801.1^{\mathrm{ab}}$ & $50,208.6 \pm 2,229.5^{\mathrm{a}}$ & $45,696.6 \pm 1,058.5^{\mathrm{bc}}$ \\
$\mathrm{RI}^{1 \mathrm{l}}(\%)$ & 100.0 & 98.9 & 106.7 & $111.7 \%$ & $101.7 \%$ \\
\hline
\end{tabular}

$\mathrm{RI}^{1)}$ : relative index, ns : not significant.

Data are expressed as means $\pm \mathrm{SD}$.

ns : not significant.

a,b,c,d Means in a row with different superscripts are significantly different $(\mathrm{p}<0.05)$. 
T4. Also, Na content was the highest in T5. P content was the highest in $\mathrm{T} 1$ which had the earliest seeding date

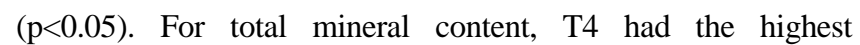
content with $50,208.6 \mathrm{mg} / \mathrm{kg}$ and T2 had the lowest with $44,477 \mathrm{mg} / \mathrm{kg}$. This is a lower result than the report from Lee (2011), which followed the liquid manure and chemical fertilizer application method, that reported 55,198.7 68,771.6 $\mathrm{mg} / \mathrm{kg}$ mineral content in Italian ryegrass. Generally it is being reported that mineral content is affected by weather conditions, soil conditions, manure conditions and other various conditions (Reid et al., 1970; Kim, 1991; Lee and Lee, 2010). However, it was a higher yield than the reports from Kim et al. (2012) which reported that mineral content in 10 varieties of silage corn had a content range of 6,790 $\sim 9,775 \mathrm{mg} / \mathrm{kg}$, and Jeon et al. (2012) which reported that the 9 varieties of Sorghum $\times$ Sudangrass hybrids had a content range of $6,222.6 \sim 15,020.5 \mathrm{mg} / \mathrm{kg}$.

\section{Composition amino acid contents}

Composition amino acid by seeding dates is listed in Table 7. First looking at essential amino acids, there was a high content of valine, phenylalanine, lysine in all treatments, but methionine content was low. The total essential amino acid content showed a trend of $\mathrm{T} 5>\mathrm{T} 4>\mathrm{T} 3>\mathrm{T} 2>\mathrm{T} 1$ $(\mathrm{p}<0.05)$. For nonessential amino acids, all treatment groups had high glutamic acid, proline and aspartic acid content. Like the essential amino acids, the nonessential amino acid content trend was $\mathrm{T} 5>\mathrm{T} 4>\mathrm{T} 3>\mathrm{T} 2>\mathrm{T} 1(\mathrm{p}<0.05)$. Total amino acid content which ranged from 8,680.9 $12,047.3 \mathrm{mg} / 100 \mathrm{~g}$ showed a similar result with the report from Lee (2012). Also, the total amino acid content was the highest in $\mathrm{T} 5$, lowest in $\mathrm{T} 1$. Result like this is considered to be attributable to the high crude protein content in $\mathrm{T} 5$, as shown in Table 5 (Ching et al., 1972; Lee, 2012). It was reported that forage crop amino acid content was 5,971 6,499 mg/100g in barley (Lee and Kim, 2013), 3,653 5,433 $\mathrm{mg} / 100 \mathrm{~g}$ in silage corn (Kim et al., 2012), and 2,324 3,908 $\mathrm{mg} / 100 \mathrm{~g}$ in Sorghum $\times$ Sudangrass hybrids (Jeon et al.,

Table 7. Effects of seeding times on composition amino acid contents of Italian ryegrass in the paddy field cultivation (DM, mg/100g)

\begin{tabular}{|c|c|c|c|c|c|}
\hline \multirow{2}{*}{ Items } & \multicolumn{5}{|c|}{ Treatments } \\
\hline & $\mathrm{T} 1$ & $\mathrm{~T} 2$ & T3 & $\mathrm{T} 4$ & $\mathrm{~T} 5$ \\
\hline Threonine & 397.1 & 447.7 & 522.1 & 554.3 & 571.3 \\
\hline Valine & 524.1 & 625.8 & 715.6 & 783.4 & 795.2 \\
\hline Methionine & 37.7 & 37.3 & 39.3 & 54.1 & 57.8 \\
\hline Isoleucine & 327.5 & 377.3 & 433.6 & 490.7 & 511.5 \\
\hline Leucine & 404.1 & 511.9 & 571.5 & 656.9 & 725.2 \\
\hline Phenylalanine & 526.7 & 609.1 & 700.5 & 750.5 & 768.5 \\
\hline Histidine & 281.7 & 331.0 & 355.4 & 361.8 & 379.3 \\
\hline Lysine & 442.0 & 503.2 & 579.2 & 601.5 & 638.4 \\
\hline Arginine & 339.1 & 388.0 & 477.3 & 472.2 & 451.7 \\
\hline Sum of EAA & $3,280.0 \pm 305.6^{c}$ & $3,831.3 \pm 335.2^{b}$ & $4,394.5 \pm 200.8^{a}$ & $4,725.4 \pm 196.1^{\mathrm{a}}$ & $4,898.9 \pm 403.2^{a}$ \\
\hline Serine & 389.7 & 397.8 & 432.8 & 452.3 & 465.2 \\
\hline Glutamic acid & $1,148.9$ & $1,311.0$ & 1,339.1 & $1,390.3$ & 1,383.3 \\
\hline Proline & $1,463.2$ & $1,598.2$ & $1,832.4$ & $2,151.2$ & $2,353.8$ \\
\hline Glycine & 319.4 & 387.4 & 436.5 & 465.8 & 458.9 \\
\hline Alanine & 525.8 & 618.9 & 669.1 & 727.2 & 765.4 \\
\hline Tyrosine & 118.3 & 118.5 & 130.6 & 123.5 & 125.3 \\
\hline Aspartic acid & $1,435.6$ & $1,543.5$ & $1,545.4$ & $1,553.3$ & $1,596.5$ \\
\hline Sum of NEAA & $5,400.9 \pm 290.9^{d}$ & $5,975.3 \pm 235.9^{c}$ & $6,385.9 \pm 433.1^{b c}$ & $6,863.6 \pm 342.2^{\mathrm{ab}}$ & $7,148.4 \pm 195.5^{\mathrm{a}}$ \\
\hline Total (EAA+NEAA) & $8,680.9 \pm 376.0^{d}$ & $9,806.3 \pm 395.7^{c}$ & $10,780.4 \pm 583.9^{b c}$ & $11,589.0 \pm 844.5^{\mathrm{ab}}$ & $12,047.3 \pm 622.2^{\mathrm{a}}$ \\
\hline
\end{tabular}

EAA: essential amino acid, NEAA: non-essential amino acid.

Data are expressed as means \pm SD.

a,b,c,d Means in a row with different superscripts are significantly different $(\mathrm{p}<0.05)$. 
2012). Therefore, it was shown that compared to barley, corn, and sorghum $\times$ sudangrass hybrids, Italian ryegrass had significantly higher amino acid content.

\section{Free sugar contents}

The free sugar content in Italian ryegrass by seeding dates is shown on Table 8. The free sugar content in Italian ryegrass was in the order of glucose $>$ sucrose $>$ fructose $>$ lactose. For fructose, T2 had the highest content with $877.4 \mathrm{mg} / 100 \mathrm{~g}$ and T5 had the lowest with 665.2 $\mathrm{mg} / 100 \mathrm{~g}(\mathrm{p}<0.05)$.

Glucose content was the highest in T5 which had the latest seeding date. Sucrose and lactose content was shown to be the highest in $\mathrm{T} 1$ and $\mathrm{T} 4$ respectively $(\mathrm{p}<0.05)$. Total free sugar was the highest in $\mathrm{T} 4$, whereas the lowest in $\mathrm{T} 5$ $(p<0.05)$. However there was no differences in total free sugar content among T1, T2, T3 and T4. Total free sugar content is lower than that of silage corn, as reported by Lee (2012), and shows a similar content as barley, reported by Lee and Kim (2013). Generally, forage crop's free sugar content is a very important ingredient because it affects the silage fermentation (Lee and Lee, 2010; Lee 2012). Especially, higher free sugar content decrease butyric acid and ammonia generation rate, and increase lactic acid yield by faster promoting fermentation of microbes. It is also reported that $\mathrm{pH}$ is maintained low so that silage stabilizes quickly (Davies et al., 1998).

\section{Nutrition yield}

The nutrition yield for Italian ryegrass is shown on Table 9. Crude protein yield showed a trend of significantly decreasing as seeding dates was delayed $(\mathrm{p}<0.05)$. T1 with the early seeding date showed an additional increase effect of about 42 43\%. Crude fat yield, mineral yield, amino acid yield, and free sugar yield were the highest in $\mathrm{T} 1$ which had the earliest seeding date $(\mathrm{p}<0.05)$. Although the $\mathrm{T} 1$ treatment has a lower crude protein, crude fat (Table 5), mineral (Table 6) and amino acid content (Table 7) than T2,

Table 8. Effects of seeding times on free sugar contents of Italian ryegrass in the paddy field cultivation (DM, $\mathrm{mg} / 100 \mathrm{~g})$

\begin{tabular}{|c|c|c|c|c|c|}
\hline \multirow{2}{*}{ Items } & \multicolumn{5}{|c|}{ Treatments } \\
\hline & $\mathrm{T} 1$ & $\mathrm{~T} 2$ & T3 & $\mathrm{T} 4$ & $\mathrm{~T} 5$ \\
\hline Fructose & $819.9 \pm 26.2^{\mathrm{b}}$ & $877.4 \pm 22.2^{\mathrm{a}}$ & $718.6 \pm 39.2^{\mathrm{c}}$ & $832.1 \pm 18.2^{\mathrm{ab}}$ & $665.2 \pm 33.3^{\mathrm{d}}$ \\
\hline Glucose & $1,323.9 \pm 147.2^{\mathrm{ns}}$ & $1,284.5 \pm 142.5$ & $1,313.1 \pm 76.9$ & $1,331.9 \pm 44.3$ & $1,432.8 \pm 39.5$ \\
\hline Sucrose & $996.3 \pm 64.8^{\mathrm{a}}$ & $809.9 \pm 40.7^{\text {bc }}$ & $878.7 \pm 32.0^{\mathrm{b}}$ & $768.7 \pm 43.3^{c}$ & $851.2 \pm 35.9^{b c}$ \\
\hline Lactose & $748.1 \pm 63.3^{\mathrm{b}}$ & $909.7 \pm 90.9^{\mathrm{ab}}$ & $935.4 \pm 53.7^{\mathrm{ab}}$ & $1,048.5 \pm 65.6^{\mathrm{a}}$ & $618 \pm 23.2^{\mathrm{c}}$ \\
\hline Total & $3,888.2 \pm 148.6^{\mathrm{a}}$ & $3,881.5 \pm 73.7^{\mathrm{a}}$ & $3,845 \cdot 8 \pm 88 \cdot 1^{\mathrm{a}}$ & $3,981 \cdot 2 \pm 97.4^{\mathrm{a}}$ & $3,549.5 \pm 120.2^{b}$ \\
\hline
\end{tabular}

Data are expressed as means $\pm \mathrm{SD}$.

ns : not significant.

a,b,c,d Means in a row with different superscripts are significantly different $(\mathrm{p}<0.05)$.

Table 9. Effects of seeding times on nutrition yield of Italian ryegrass in the paddy field cultivation (DM, $\mathrm{kg} / \mathrm{ha}$ )

\begin{tabular}{cccccc}
\hline \multirow{2}{*}{ Treatments } & \multicolumn{5}{c}{ Nutrition yield (kg/ha) } \\
\cline { 2 - 6 } & Crude protein & Crude fat & Mineral & Amino acid & Free sugar \\
\hline \hline T1 & $627.7 \pm 44.7^{\mathrm{a}}$ & $93.7 \pm 6.7^{\mathrm{a}}$ & $183.2 \pm 13.1^{\mathrm{a}}$ & $353.8 \pm 25.3^{\mathrm{a}}$ & $158.4 \pm 11.2^{\mathrm{a}}$ \\
T2 & $489.0 \pm 60.4^{\mathrm{b}}$ & $64.2 \pm 8.1^{\mathrm{b}}$ & $135.9 \pm 16.7^{\mathrm{b}}$ & $299.7 \pm 36.9^{\mathrm{b}}$ & $118.6 \pm 14.7^{\mathrm{b}}$ \\
T3 & $428.2 \pm 47.1^{\mathrm{bc}}$ & $55.6 \pm 6.2^{\mathrm{bc}}$ & $111.0 \pm 12.2^{\mathrm{bc}}$ & $249.5 \pm 27.4^{\mathrm{c}}$ & $89.0 \pm 9.8^{\mathrm{c}}$ \\
T4 & $358.6 \pm 40.3^{\mathrm{c}}$ & $46.4 \pm 5.2^{\mathrm{c}}$ & $89.6 \pm 10.1^{\mathrm{c}}$ & $206.7 \pm 23.2^{\mathrm{c}}$ & $71.0 \pm 8.0^{\mathrm{cd}}$ \\
T5 & $364.6 \pm 37.4^{\mathrm{c}}$ & $51.3 \pm 5.3^{\mathrm{c}}$ & $85.3 \pm 19.6^{\mathrm{c}}$ & $206.2 \pm 21.2^{\mathrm{c}}$ & $60.5 \pm 6.2^{\mathrm{d}}$ \\
\hline
\end{tabular}

Data are expressed as means \pm SD.

ns : not significant.

a,b,c,d Means in a column with different superscripts are significantly different $(\mathrm{p}<0.05)$. 
T3, T4, and T5, but the high nutrition yield of $\mathrm{T} 1$ is caused by the result of the significantly higher dry matter yield. Kim et al. (2012) reported that even if crude protein, crude fat, and minerals are higher, nutrition yield will be lower if dry matter yield is low. It is reported that the yield of Italian ryegrass which is grown after rice harvest at the paddy is higher as seeding date is sooner (Kim et al., 2009). Therefore, to increase yield of Italian ryegrass in the midlands after rice cultivation, it is favorable to seed soon after rice cultivation.

\section{ACKNOWLEDGEMENTS}

This research was supported by Kyungpook National University Research Fund, 2012.

\section{REFERENCES}

AOAC. 1995. Official Methods of analysis. 16th ed. Association of analytical chemist, Washington, DC., USA.

Chae, J.S., Kim, Y.D., Kim, H.J. and Park, T.I. 1996. Growth characteristics and matter yield ability according to seed production time of Italian ryegrass. Journal of the Korean Society of Grassland Science. 16:39-46.

Ching, Y.H., Lee, C.Y., Kim, S.C., Lee, C.W., Kim, K.S. and Yoon, C.Y. 1972. Studies on amino acids in feed stuffs. Korean Journal of Animal Science. 14:224-229.

Choi, G.J., Lim, Y.C., Kim, K.Y., Kim, M.J., Ji, H.C., Lee, A.H., Park, H.S., Moon, C.S., Lee, E.S. and Seo, S. 2008. A cold-tolerant and medium-maturing Italian ryegrass (Lolium multiflorum Lam) new variety, 'Kowinmaster'. Journal of the Korean Society of Grassland Science. 28:177-184.

Choi, G.J., Lim, Y.C., Kim, K.Y., Sung, B.R., Rim, Y.W., Kim, M.J., Lim, K.B. and Seo, S. 2006a. A cold-tolerant and highyielding Italian ryegrass new variety, 'Kowinner'. Journal of the Korean Society of Grassland Science. 26:171-176.

Choi, G.J., Lim, Y.C., Sung, B.R., Kim, K.Y., Lee, J.K., Lim, K.B., Park, H.S., Seo, S. and Ji, H.C. 2007. A cold-tolerant and early-maturing Italian ryegrass (Lolium multiflorum Lam.) new variety, 'Kospeed'. Journal of the Korean Society of Grassland Science. 27:145-150.

Choi, G.J., Lim, Y.C., Rim, Y.W., Sung, B.R., Kim, M.J., Kim, K.Y. and Seo, S. 2006b. A cold-tolerant and high-yielding Italian ryegrass new variety, 'Kogreen'. Journal of the Korean Society of Grassland Science. 26:9-14.
Choi, G.J., Rim, Y.W., Sung, B.R., Lim, Y.C., Kim, M.J., Kim, K.Y., Park, G.J., Park, N.K., Hong, Y.K. and Kim, S.R. 2005. Growth characters and productivity of Italian ryegrass (Lolium multiflorum L.) new variety "Hwasan 104". Journal of the Korean Society of Grassland Science. 25:275-280.

Davies, D.R., Merry, R.J., Williams, A.P., Bakewell, E.L., Leemans, D.K. and Tweed, J.K.S. 1998. Proteolysis during ensilage of forage varying in soluble sugar content. Journal of dairy Science. 81:444-453.

Goring, H.K. and Van Soest, P.J. 1970. Forage fiber analysis. Agic. handbook. No. 379. ARS. USDA. Washington DC.

Hwang, K.J., Ko, S.B., Park, H.S., Park, N.G., Ko, M.S., Jeong, H.Y., Kim, M.C., Song, S.T. and Kim, D.W. 2008. Effects of the cutting time on forage yield and quality in Italian ryegrass (Lolium-multiflorum Lam.) and oat (Avena sativa L.) seeded singly or in combination. Journal of the Korean Society of Grassland Science. 28:295-300.

Jeon, B.T., Moon, S.H. and Lee, S.M. 2012. A comparative studies on the growth characteristics and feed components of sorghum $\times$ sudangrass hybrids at paddy field cultivation. Journal of Korean Society of Grassland and Forage Science. 32:29-38.

Kim, D.A., Kim, M.C., Chun, U.B., Shin, C.N., Kwon, C.H., Kum, J.S. and Lim, S.H. 1998. Evaluation of the government recommended forage cultivars in Korea. V. Forage performance and quality of Italian ryegrass cultivars. Journal of the Korean Society of Grassland Science. 18:11-18.

Kim, M.C. 1991. Effects of nitrogen and potassium application on pasture of Cheju volcanic ash soil. I. Dry matter yield and mineral concentration $(\mathrm{N}, \mathrm{P}, \mathrm{K}, \mathrm{Ca}, \mathrm{Mg}, \mathrm{Na})$ of orchard grass. Korean Journal animal Science. 33:683-691.

Kim, M.J., Choi, G.J., Yook, W.B., Lim, Y.C., Yoon, S.H., Kim, J.G., Park, H.S. and Seo, S. 2007. Effects of seeding method on the winter survival, dry matter yield and nutrient value of Italian ryegrass in paddy field. Journal of the Korean Society of Grassland Science. 29:321-328.

Kim, M.J., Choi, K.J., Kim, J.G., Seo, S., Yoon, S.H., Lim, Y.C., Im, S.K., Kwon, E.G., Chang, S.S., Kim, H.C. and Kim, T.I. 2009. Effect of varieties and seeding date on over winter and dry matter yield of Italian ryegrass in paddy field. Journal of the Korean Society of Grassland Science. 29:321-328.

Kim, W.H., Seo, S., Shin, J.S., Lim, Y.C., Kim, K.Y., Jung, M.W. and Kim, T.H. 2006. Effect of seeding date and rate on the agronomic characteristics and yield of forage barley. Journal of the Korean Society of Grassland Science. 26:155-158.

Kim, W.S., Hwang, J.H., Lee, J.H., Kim, E.J., Jeon, B.T. and Lee, S.M. 2012. A comparative study on te growth characteristics and 
nutritional components of corn hybrids for silage at paddy field cultivation. Journal of Korean Society of Grassland and Forage Science. 32:15-28.

Kim, Y.K., Lee, M.J., Kim, N.J., Seo, J.H., Choi, J.S., Hyun, J.N., Park, J.C., Kim, J.G. and Jonson, G. 2008. Growth and yield of Naked barley cultivars in different seeding date. Journal of Life Science and Natural Resources. 30:59-67.

Lee, S.M. 2011. Effects of application of fermented swine manure on the growth characteristics and yields of Italian ryegrass in paddy field. Journal of Ecology and Environmental Science. 3:162-167.

Lee. S.M. 2012. Effects of application of fermented swine manure on amino acid and fatty acid compositions of Italian ryegrass in paddy field. Journal of Ecology and Environmental Science. 4:127-131.

Lee, S.H. and Kim, E.J. 2013. Study on nutritive values of whole crop barley varieties grown in a paddy field. Journal of the Korean Society of Grassland and Forage Science. 33:30-38.

Lee, S.M. and Lee, J.H. 2010. Effects of seeding dates and growth periods on the growth characteristics, dry matter yield and feed value of corn for silage in paddy field. Korean. Journal of Animal Science and technology. 52:441-448.

Lim, S.H. and Kim, D.A. 1996. Effect of different harvest dates on dry matter and forage quality of corn (Zea mays L.). Journal of the Korean Society of Grassland Science. 16:75-80.

Menke, K.H. und Huss, W. 1980. Tieremaehrung und futtemittelkunde. UTB Ulmer. pp. 38-41.

Park, M.S., Lee, K.S. and Lee, J.H. 1986. Studies on the characteristics of grain development process for Baegdong in double cropping paddy. Korean Journal Crop Science. 31:91-96.

Reid, R.L., Post, A.J. and Jung, G.A. 1970. Mineral composition of forage. W. Va. Agr. Exp. Sta. Bull. pp. 589.

SAS. 2010. SAS/STAT software for PC. Release 9.3, SAS Institute INC., Cary, NC, USA.

Seo, S., Kim, M.J., Kim, W.H., Lee, S.H., Jung, M.W., Kim, K.Y., Ji, H.C., Park, H.S., Kim, J.G. and Choi, G.J. 2013. Optimum harvest stage of Italian ryegrass 'Kowinerly' according to one and two harvests during spring season. Journal of the Korean Society of Grassland and Forage Science. 33:15-20.

Suh, H.S. 1981. Comparison of several agronomic characteristics as affected by seeding dates. Korean Journal Crop Science. 26:298303.

Willson, A.M., Work, T.M. and Bushway, A.A. 1981. HPLC determination of glucose and sucrose in potatoes. Journal of Food Science. 46:300-306.

(Received August 17, 2013/Revised September 15, 2013 / Accepted September 20, 2013) 